\title{
TRIPs Agreement and Enforcement of the Intellectual Property Rights in China*
}

\author{
Zhongfa Ma** \& Yan Zhang***
}

It is generally accepted that China's legislation including the provisions on enforcement of intellectual property rights has met the requirements of the TRIPS agreement and its government has exerted best efforts to enforce intellectual property laws, as illustrated by the institution of executive bodies, the dual-track approach system for protecting IPRs and other actions in this field. However, enforcement of IPRs is still a critical problem for China to solve because the protection standards of IPRs are beyond its economic development and education level, local protectionism interferes with enforcement, insufficient severity of punishment against infringers fails to deter, the price of genuine IP products is overinflated and a legal culture of not observing laws in China. To eliminate the roots of difficulties in enforcing IP laws, awareness of protecting IPRs and abiding by IP laws should be improved. Also, the IPR enforcement system should be further perfected by, centralizing the power of $I P R$ enforcement by merging the current executive bodies into fewer ones with certain focuses, increasing the severity of punishment against infringers of IPRs and cracking down against local protectionism.

* The paper is the fully revised version of the draft manuscript submitted to and presented at the International Conference on "New Legal Order in Asia and Europe" organized by Law Research Institute, University of Seoul, Korea on January 11, 2012. Our great thanks shall be extended to the organizers, Professor Yong-soo Won and Professor Chang-wee Lee, the Discussant, Professor Chan-mo Chung (Inha University Law School) and the participants, especially to Professor Deok-young Park (Yonsei University Law School). The authors would also like to acknowledge the sponsorship from Shanghai Municipality Education Commission which supports the Project on "Studies on Legal System of Technology Transfer and Construction of an Innovative Country" (No: 10ZS07).

** Associate Professor of Law at Fudan University School of Law, P.R. China. B.A.(Anhui Normal Univ.), LL.M./Ph.D.(Fudan). The author may be contacted at: zfma@fudan.edu.cn / Address: Law School, Fudan University, 2005 Songhu Road, Shanghai, P.R. China, 200438.

*** Associate Professor of Law at the Teaching and Research Institute of Political Theory, Zhejiang University, P.R. China. LL.B./Ph.D. (Zhjiang). The author may be contacted at: zhangyanzju@zju.edu.cn / Address: 866 Yuhangtang Road, Hangzhou, Zhejiang Province, 310058 P. R. China. 


\author{
Keywords \\ Enforcement of Intellectual Property Rights, Intellectual Property Laws, \\ TRIPS Agreement, Dual-Track Approach System, Special Campaign \\ against IPR infringement
}

\title{
I. Introduction
}

Thirteen years after the entry into force of the Agreement on Trade-related Aspects of Intellectual Property Rights (hereinafter TRIPs Agreement), strengthening enforcement ${ }^{1}$ of the intellectual property rights ("IPRs") became a critical issue in many multi- and bilateral negotiations. ${ }^{2}$ A current and clear illustration of this is the conclusion of the AntiCounterfeiting Trade Agreement ("ACTA"), 3 which focuses on issues of enforcing intellectual property rights in the world. However, the enforcement of intellectual property ("IP") laws has its own inherent rules and particular characteristics. The enforcement of IPRs requires the close collaborations of governments, enterprises, nongovernmental organizations and individuals. In addition, the enforcement utilizes a severe comprehensive sanction mechanism. If these rules and characteristics are neglected or dealt with inappropriately, the results may run counter to the intent, and gross inefficiencies can occur. 4

Currently, it is commonly recognized that the People's Republic of China has

1 There are some differences between law enforcement and law implementation. Law enforcement broadly refers to any system by which some members of society act in an organized manner to promote adherence to the law by discovering and punishing persons who violate the rules and norms governing that society. See K. HESS \& C. Orthmann, Introduction to LAW EnForcement And Criminal Justice 1 (2008). In legal science, law implementation means laws made by legislatures are executed by public servants working in bureaucratic agencies, enforced by judicial branches and respected by enterprises, other organizations and individuals in a country or a territory; enforcement of laws may be thus key parts of implementation of laws. In this paper, enforcement of law refers to executions of law by the executives and enforcement of law by the judicatures.

2 Xuan Li, Ten General Misconceptions About the Enforcement of Intellectual Property Rights, in INTELLECTUAL Property Enforcement - International Perspectives 14 (Xuan Li \& C. Correa eds. 2009).

3 It is a proposed plurilateral agreement for establishing international standards on the IPR enforcement and is open for signature until March 31, 2013. The idea to create a plurilateral agreement on counterfeiting was developed by Japan and the United States in 2006. For the details of the development history of ACTA, see Miriam Bitton, Rethinking the Anti-Counterfeiting Trade Agreement's Criminal Copyright Enforcement Measures, 102 J. CRIM. L. \& Criminology 68-72 (2012). For details on the parties signing it, see Jason Walsh, Europe's Internet Revolt: Protesters See Threats in Antipiracy Treaty, The Christian ScIEnce Monitor, Feb. 11, 2012.

4 One scholar used a Chinese proverb, "You can lead a horse to water, but you cannot make it drink" to express the similar meaning. See G. Feder, Enforcement of Intellectual Property Rights in China: You Can Lead a Horse to Water, but You Can't Make It Drink, 37 VA. J. INT' L L. 223. 
already established a comprehensive legal system to protect the IPRs according to international treaties or agreements. 5 Although the IPRs system has generally met the requirements of the key international treaties, the United States and the European Union have often accused China of not performing its obligations of enforcing IP laws effectively. ${ }^{6}$ In fact, the Chinese government has paid much attention to implementing the IP laws and has been exerting great effort to fight against the IPR infringements for a long time. Since 1998, the Central People's Government of China has released annual white papers on the China's Intellectual Property Protection in order to evaluate the situation and achievements of the previous years; enforcing IP laws has always been a critical part of the white papers.7 Since 2006, the State Intellectual Property Office ("SIPO") and other ministries of the State Council have jointly issued the China's Action Plans on the IP Protection every year focusing on the enforcement of the IP laws. 8 In 2008, the Trademark Office and the Trademark Review and the Adjudication Board of State began to issue the Annual Development Report on the China's Trademark Strategy, the main part of which is to enforce trademark law.9 Since 2009, the Supreme People's Court has published annual white papers on the Intellectual Property Protection by the Chinese Courts. 10 In the past two years, the Promotion Plans for the Implementation of the National Intellectual Property Strategy (hereinafter the Plans) in 2011 and 2012 have respectively been promulgated by the Office of the Inter-Ministerial Joint Meeting for Implementation of the National Intellectual Property Strategy. In the Plans, the most significant sections discussing "Strengthening IP Protection” contain: (1) formulations for revising IP laws, regulations and regulatory documents; and (2) suggestions for improving IPRs enforcement including special enforcement campaigns, strengthening regular enforcement and increasing the judicial protection for IPRs. ${ }^{11}$ As

5 Handong Wu, A Review and Reflection on China's IP Legal Construction, 1 CHINA LEGAL ScI. 51-53 (2009).

6 Over 15 years ago, some Chinese scholars mentioned this issue in their papers. See, e.g., Naigen Zhang, Intellectual Property Law Enforcement in China: Trade Issues, Policies and Practices, 8 Fordham InTELl. Prop. Media \& Ent. L. J. 1 (1997). Today, the situation of the complaints made by the United States and European Union has not changed fundamentally.

7 See The Annual Status of China's Intellectual Property Protection since 1998 (available only in Chinese), available at http://www.nipso.cn/bai.asp (last visited on Oct. 21, 2012).

8 See SIPO, Law \& Policy, available at http://english.sipo.gov.cn/laws (last visited on Oct. 21, 2012).

9 See Statistic Information (available only in Chinese), available at http://sbj.saic.gov.cn/tjxx (last visited on Oct. 21, 2012).

10 See Intellectual Property Protection by Chinese Courts in 2009 (中国法院知识产权 司法保护状况, 2009年) (available only in Chinese), available at http://www.ipr.gov.cn/zfxxarticle/govinfo/govtjxx/201005/935904_1.html (last visited on Oct. 21, 2012); Supreme People's Court of P.R.C., Intellectual Property Protection by Chinese Courts in 2010 (中国法院知识产权司法保护状况, 2009年) (available only in Chinese), available at http://www.Court.gov.cn/qwfb/ sfwj/tz/201112/t20111212_168179.htm (last visited on Oct. 21, 2012).

11 For details, see SIPO, The Promotion Plan for the Implementation of the National Intellectual Property Strategy in 2011, available at http://english.sipo.gov.cn/laws/developing/201104/t20110426_601292.html; SIPO, Promotion Plan 
these papers and activities show, China has not only tried its best to ensure its legal system fairly protects the IPRs, adopted forceful measures to enforce the IPRs as efficiently as possible.

However, due to reasons such as poor education, lack of awareness of IP laws, and other cultural, economic and administrative factors, Chinas' enforcement activities have seldom satisfied the expectations of its major trading partners including the U.S., EU, Japan and Korea. However, these nations should recognize that making a law is easier than enforcing it. International law and public opinions may produce immediate and positive effects in the lawmaking process, but they have little influence on the enforcement of law. In the 19th century, e.g., there were many patent infringement cases in the U.S. in spite of advanced patent system. 12 When talking about the enforcement question of IP laws, many other social, economic and cultural conditions should be taken into consideration. Developing countries could not eliminate their IP infringements within a short time just as many English writers in the 19th century did not expect the U.S. government to completely sweep away illegal reproduction of their copyrighted works. 13 Nations seeking greater enforcement of the IPRs need time to overcome a number of difficulties which are now standing before them.

The preliminary purposes of this paper are: (1) to demonstrate the objective situations of the enforcement of IP laws in China; (2) to find various difficulties in enforcing IP laws in China; and then (3) to explore realistic and effective ways to enforce the IP laws in light with the TRIPs Agreement. This paper is composed of six parts including Introduction and Conclusion. Part two will briefly describe the overall state of the IPR legal system in China since 1978. Part three will analyze the current situations of the IP laws enforcement and figure out the reasons for the problems. Part four will focus on the gaps between what China has done so far and what the TRIPs Agreement requires in respect of IPR enforcement. Part five will discuss the difficulties of enforcing the IP laws in China and try to explore the reasons for them.

for the Implementation of the National Intellectual Property Strategy in 2012, available at http://english.sipo.gov.cn/ laws/developing/201204/t20120410_667158.html (last visited on Oct. 21, 2012).

12 Xiaoqin Wang, The Capital for Starting an Undertaking-From Benjamin Franklin to Bill Gates 161 \& 287-290 (2003).

13 In this aspect, Charles Dickens is the most distinguished example. In the 1830s, Charles Dickens' 'Christmas Carol' was sold for six cents a copy in America, versus USD2.50 in England; Mr. Dickens was very irritated and toured the United States in 1842, urging the adoption of international copyright protection as being in the long-term interest of American authors and publishers. See S. Lohr, New Economy-The Intellectual Property Debate Takes a Page from $19^{\text {th }}$ Century America, N. Y. TIMES, Oct. 14 2002, at C4. 


\section{The IPRs Enforcement in the TRIPs Agreement and Chinese Legislation: A Comparison}

\section{A. Provisions on the Enforcement of the IPRs in the TRIPs Agreement}

The enforcement of the IPRs is a very important part of the TRIPs Agreement. Composed of 21 articles, Part III of the TRIPs Agreement focuses on four specific aspects of enforcing IPRs such as civil, administrative and criminal procedures, and customs protections. The provisions on general obligations set four principles for enforcing IPRs as follows: (1) the specified procedures under domestic laws are to permit effective action against any act of IPR infringement; (2) the related procedures should be fair and equitable, not unnecessarily complicated or costly, or entailing unreasonable time-limits or unwarranted delays; (3) decisions on the merits of a case are to be made on the basis of sufficient evidence and hearings; and (4) a judicial review system on final administrative decisions is to be provided by members of the WTO, but as for acquittals in criminal cases, members have no obligation to provide an opportunity for such review. 14 The regulation on provisional measures empowers the judicial authorities to order prompt and effective provisional measures to prevent any existing or potential IPR infringement before the right holders file lawsuits in the court. This measure contains the issuing pre-interim injunctions and the adopting provisional measures of property preservation or evidence preservation upon the applications of related parties. 15 Noticeable is that, in order to offset the strengths of the four principles, 16 or to consider the requirements of developing member States, the TRIPs Agreement does not create any obligation to put in place a system for the enforcement of the IP laws that would be separate and distinct from the general enforcement judicial system. 17 The purpose for adopting such provisions would show that the WTO members do not want to bear any extra burden of enforcing IP laws except for the general enforcement system.

However, words and phrases such as 'effective,' "fair and equitable," "unreasonable time-limits (timely)," 'unnecessarily' or 'reasonable' are too flexible to be specified under a universal and objective standard, because many developing countries little experienced the IPR enforcement and the true meaning of the above mentioned words would be mainly interpreted by developed countries. In addition, many provisions of

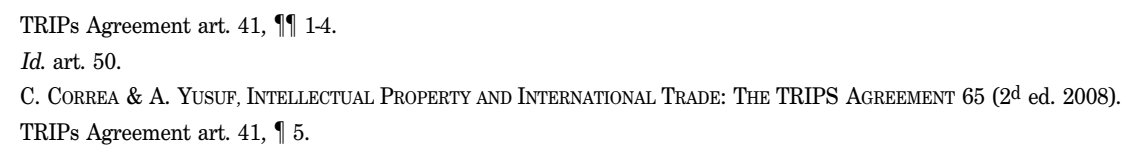


the TRIPs Agreement are similar to the U.S. laws. E.g., Article 43 (which contains the concept of fair and equitable procedures 18 ) takes after the U.S. law. ${ }^{19}$ As for damages calculation in general, moreover, the related provision in the TRIPs Agreement 20 clearly was influenced by the U.S. law when it was drafted.21 It is understandable why the U.S. filed two applications on the enforcement of the IP laws in China to the WTO Dispute Settlement Body ("DSB") in 2007.22 The U.S. thus holds significant advantages in such cases mainly because of the following reasons: (1) the words used in the TRIPs Agreement are flexible and interpreted in an English context; (2) some articles are derived from the U.S. domestic laws; and (3) English is spoken in the hearings. Consequently, the proceedings of the WTO DSB might be similar to those of U.S. domestic cases. Article 46 of the TRIPs Agreement states as follows:

In order to create effective deterrence to infringement, the judicial authorities shall have authority to order that goods that they have found to be infringing shall either be ... disposed of outside the channels of commerce ... or ... be destroyed by the judicial authorities; and materials and implements predominantly used in the creation of the infringing goods shall be ... disposed of outside the channels of commerce ... and in regard to counterfeit trademark goods, the simple removal of the trademark unlawfully affixed shall not be sufficient ... to permit release of the goods into the channels of commerce. 23

This provision is intended to declare that any goods produced that infringe IPRs shall not be allowed to enter into commercial channels in any form or shall be destroyed, except for extremely special cases. Also, any materials and implements used for producing such goods shall not be used in a commercial fashion. These are the basic requirements for the WTO members dealing with the infringing products or goods or materials and implements used for producing such goods, under the precondition that such goods, materials or implements have been found to be infringed upon certain IPRs.

Most of the provisions on the IPR enforcement are measures applied to civil procedure; judicial authorities shall enforce the IP laws except the only provision that

19 Correa, supra note 16 , at 66.

20 TRIPs Agreement art. 45.

21 See Remedies for Infringement: Costs and Attorney's Fees, 17 U.S.C. $§ 505$; Attorney Fees, 35 U.S.C. § 285 ; and 15 U.S.C. cl. 1117 (a) (3).

22 See WTO, China - Measures Affecting the Protection and Enforcement of Intellectual Property Rights, WT/DS362/R (Jan. 26, 2009), available at http://www.worldtradelaw.net/reports/wtopanelsfull/china-iprights(panel)(full).pdf (last visited on Oct. 21, 2012); China - Measures Affecting Trading Rights and Distribution Services for Certain Publications and Audiovisual Entertainment Products, WT/DS363/AB/R (Oct. 21, 2009).

23 TRIPs Agreement art. 46. 
stipulates that the procedures shall conform to principles equivalent in substance in the Part.24 However, this does not mean that the WTO members must establish an administrative settlement mechanism for the IPR disputes, especially that of the remedies by making infringers compensate the IPR holders for their loss. Essentially, there is no substantive content concerning administrative procedures for directly protecting IPRs. As for criminal procedures, only one provision requires members to provide for criminal procedures and penalties to be applied "at least in the cases of willful trademark counterfeiting or copyright piracy on a commercial scale." 25 Thus, there is no provision concerning criminal liability for patent infringement committed in the TRIPs Agreement.

Regarding border measures, ten articles require members to absorb certain measures into domestic laws. These provisions are more specific and definite than other provisions in this part. 26 However, they do not mention how to deal with products which may be manufactured or produced in way that infringes IPRs when such products are transported by way of just in-transit passage, that is, transported through the border but not cleared by the customs of the transit countries, to a third country. This issue is a critical part of the ACTA.

Even though the provisions of the TRIPs Agreement are generally advantageous to the developed countries, they are still unsatisfied with the provisions on enforcement of IP laws. Those countries continually endeavor to revise the provisions with 'flaws' or seek 'remedies' in other ways. Thus, developing countries have signed numerous bilateral or multilateral agreements with their trading partners without involvement of the WTO system. In the bilateral free trade agreements ("FTAs"), IPR enforcement is more stringent than the TRIPs Agreement. The U.S., taking advantage of this form, had already signed 17 FTAs with other countries by the end of 2011.27 The multilateral agreements concentrate on enforcing IP laws. If entered into force, the ACTA will produce impacts on the enforcement of IP laws in the both contracting and noncontracting parties which have trade relationship with the ACTA.

\section{B. Legislation on the IPRs Enforcement in China ${ }^{28}$}

In the field of IP legal systems, it may be easier for a country to make and revise its IP domestic laws within a limited time to comply with international IP treaties than to

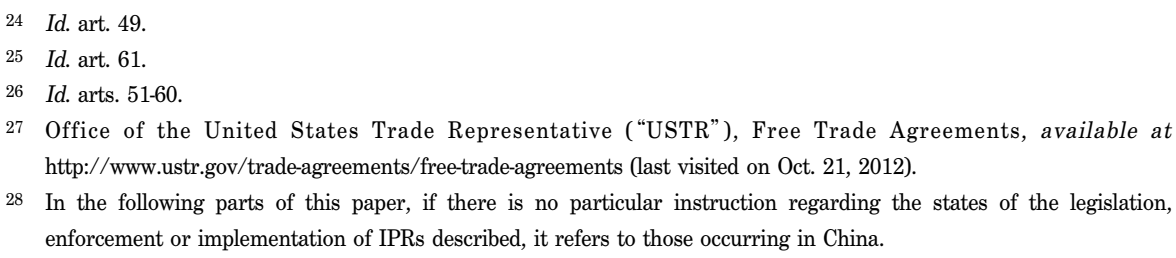


enforce them owing to numerous conditions. China is a glaring example in this aspect. It was successful in enacting the IPR legislation, but is facing many difficulties and challenges in enforcing these laws. The IPR legislation in China can be divided into two phases: (a) from 1978 to 2000, under the open-door policy, the legislation was predominantly influenced by the World Intellectual Property Organization ("WIPO")29 and the pressures of the United States 30 ; and (b) since 2000, however, the legislation has been decisively driven by the enforcement of the TRIPs Agreement and the endogenous demands of China's own social and economic development. ${ }^{31}$

\section{Laws on IPRs}

Since 1978, China has gradually established and perfected its comprehensive legal system on IPRs. In the field of the IP legislation in China, the Constitution of the People's Republic of China (hereinafter the Constitution) 32 contains eight provisions concerning the IP protection. Table II-1 shows the provisions of the Constitution relating to the IP protection.

Table II-1: Regulation of the P.R.C. Constitution regarding the IP Protection

\begin{tabular}{|c|l|}
\hline Provisions & \multicolumn{1}{c|}{ Regulation } \\
\hline Articles 6, 11 \& 13 & Protections of public and private properties \\
\hline Articles 9 \& 21 & $\begin{array}{l}\text { Natural resources and health, which involve new varieties of plants, gene } \\
\text { patents and traditional Chinese medicine }\end{array}$ \\
\hline Articles 20, 22 \& 47 & $\begin{array}{l}\text { Enactment of the IP laws, which respectively provide that the state } \\
\text { promotes the development of the natural and social sciences, } \\
\text { disseminates knowledge of science and technology, art and literature ... } \\
\text { commends and rewards achievements in scientific research and } \\
\text { technological innovations and inventions, and sponsors mass cultural } \\
\text { activities; and that citizens have the freedom to engage in scientific } \\
\text { research, literary and artistic creation and other cultural pursuits; and the } \\
\text { state encourages and assists creative endeavors conducive to the interests } \\
\text { of the people ... engaged in education, science, technology }\end{array}$ \\
\hline
\end{tabular}

Source: Compiled by the author.

29 For details, see Zhongfa Ma, Introduction and Interactivities of Intellectual Property System: WIPO and China, 4 INT'L REv. 26-33 (2009).

30 W. Alford, To Steal a Book is An Elegant OfFEnse 112-123 (1995).

$31 \mathrm{Wu}$, supra note 5 , at 53-54.

32 The Constitution was enacted in 1982 and revised in 1988, 1993, 1999, and 2004, respectively. See the Constitution of P.R.C (available only in Chinese), available at http://www.gov.cn/gongbao/content/2004/content_62714.htm (last visited on Oct. 21, 2012). 
Beginning in 1982, China promulgated the Trademark Law (1982), the Patent Law (1984), the Copyright Law (1990), and the Anti-unfair Competition Law (1993); each of the first three was revised until 2010. In China, the interpretations of the Standing Committee of the National People's Congress and by the Supreme People's Court ("SPC") or the Supreme People's Procuratorate ("SPP"), or any of those, have legal bindings all over the country. They are regarded as an important and complementary part of the related laws and kinds of legal resources. Up to the end of 2009, the SPC published 41 judicial interpretations relating to IPRs, 29 of which were in force. 33 From January 1, 2010 to May 31, 2012, the SPC and the SPP have jointly promulgated one additional document, "Interpretation on Applicable Laws to the Trial of Criminal Cases of Threatening Computer Information System Security." 34 Among these interpretations, Interpretations I35 and II 36 by the SPC and the SPP on "Several Issues of Concrete Application of Laws in Handling Criminal Cases of Infringing IPRs" are the most distinguished ones, which provide for very powerful instruments for striking at the crime of the IPR infringement.

In addition, the Criminal Law, the General Principles of the Civil Law and the Tort Liability Law contain some provisions concerning the IPRs protection. The provisions in these laws, combined with the specialized laws and interpretations, constitute a relatively comprehensive legislative system for protecting the IPRs in China. If the provisions in the abovementioned IP laws are compared with those in the TRIPs Agreement and other international IP treaties, it will be found that the former are in compliance with the latter. In view of performing its obligations described in international IP treaties acceded to or ratified by China, China has an advanced legal system of the IP legislation which has met all requirements. 37

The Copyright Law, the Patent Law and the Trademark Law specifically contain the provisions on the IPR enforcement complied with the TRIPs Agreement, which lay the foundations for the related regulations and rules. The most outstanding instances are Chapter Six of the Copyright Law on Legal Liabilities and Enforcement Measures,38

\footnotetext{
33 See People's Court Daily, Intellectual Property Protection by Chinese Courts in 2009, People's Court DaILy, May 12, 2010. As the first publication concerning this issue in China, the Paper includes a brief introduction of intellectual property protection in China in the last 30 years.

34 For details, see SPC \& SPP, Interpretation on Applicable Laws to the Trial of Criminal Cases of Threatening Computer Information System Security, Procuratorial Daily, Aug. 30, 2011, at 3.

35 Published on Dec. 8, 2004, and entered into force on Dec. 22, 2004.

36 Published and entered into force on Apr. 5, 2007.

37 See Shunde Li, Protection of Intellectual Property has been Improved Year by Year and China's Efforts have Been Obviously seen by All (中国知识产权保护水平逐年提高 努力有目共睹) (Apr. 19, 2007) (available only in Chinese), available at http://finance.sina.com.cn/g/20070419/09403516702.shtml (last visited on Oct. 21, 2012).

38 Copyright Law art. 48.
} 
Chapter Seven of the Patent Law on Protection of Patent Rights, 39 and Chapter Seven of the Trademark Law on Protection of the Exclusive Right to the Use of a Registered Trademark. 40 Most of these provisions focus on IPR enforcement reflecting the main contents of the TRIPs Agreement.

\section{Regulations or Rules on the Enforcement of IP Laws}

The IP laws in China are enforced by a large number of stipulations. The IPRs may be enforced in China by either the executive bodies or judicial departments. The former is called administrative enforcement of IP laws, and the latter is considered judicial enforcement of IP laws.41 The Chinese government has always been enhancing the enforcement of its IP laws as one of its major duties. To implement, the IP laws shall be accomplished via promulgation of necessary regulations or rules. These regulations or rules laid down by the executives can be classified at three levels.

The regulations at the first level are those made by the State Council which is the highest administrative organ of the country. From 1979 to 2011, 16 key regulations on the IP law enforcement were promulgated, including Implementing Regulations of the Patent Law (1985), Regulations of the Trademark Law (1983), Implementing Regulations of the Copyright Law (1991), Regulations on Customs Protection of Intellectual Property Rights (1995), Regulations on the Protection of New Varieties of Plants (1997), Regulations for the Protection of Layout-design of Integrated Circuits (2001), Regulations on the Administration of Special Signs (1996), Ordinance on the Protection of the Right to Network Dissemination of Information (2006), Regulation for Computer Software Protection (1991), and the Collective Management of Copyright Regulations (2004). 42 These regulations shall be carried out throughout mainland China and their legal effects prevail over those of administrative rules, ordinances or orders.

The rules or ordinances at the second level are those made by the ministries or commissions of the State Council, especially by the SIPO, the National Copyright Administration of China ("NCAC"), the State Administration for Industry and Commerce ("SAIC") and the Ministry of Science and Technology. There are about 100 rules, orders or ordinances in force to enforce the IP laws in China. All of these rules are implemented all over the nation.

39 Patent Law art. 60.

40 Trademark Law art. 53.

41 See State Council of the P.R.C., Outline of the National Intellectual Property Strategy of China 9, available at http://english.gov.cn/2008-06/21/content_1023471.htm (last visited on Oct. 21, 2012); Handong Wu, The Leading Role Played by Judicial Protection, PeOPLE's Court DAILY, July 21, 2010.

42 For English version, see SIPO, Law \& Policy, available at http://english.sipo.gov.cn/laws/ (last visited on Oct. 21, 2012). 
The regulations or rules at the third level are those made by different local peoples' congresses and governments, such as the provincial and municipal authorities and subprovincial and sub-municipal authorities. These laws are called local regulations or rules and are implemented within certain local regions. However, they may be more important for effective enforcement of IP laws, as nationwide regulations or rules mostly depend on the implementation of local activities.

The judicial enforcement of IP laws is also important in China. In addition to judicial interpretations, more than 40 very influential judicial guidance documents have been issued for the past 30 years instructing the lower courts on how to enforce IP laws. 43 For example, the latest documents were issued in concert both by the SPC, the SPP, the Ministry of Public Security ("MPS") and the Ministry of Justice on January 10, 2011,44 and by the SPC on December 16, 2011.45 Those documents have made the IP-related provisions in the Criminal law and judicial interpretations more operable and easy to enforce.

\section{Activities of Enforcing IP Laws by the Administrative and Judicial Bodies}

As the above mentioned, in China, IP laws are enforced by administrative as well as judicial organs. Enforcing IP laws by administrative organs can be further classified into two kinds: one is routine administrative activities, such as IPR examination, granting exclusive rights and registration (including that of licensing, assignment and renewal, alterations); the other involves protection of IPRs through administrative procedures, including relief measures provided by and special campaigns to protect IPRs launched

43 Supra note 33.

44 SPC, SPP \& The Ministry of Justice of P.R.C., Opinions on Several Issues Concerning the Application of the Law in Handling Criminal Cases of Intellectual Property Infringement (关于办理侵犯知识产权刑事案件适用法律若干问题的意见), 3 FAFA 〈法发〉 (2011), available at http://www.chinalawandpractice.com/Article/2780419/Channel/9950/Opinion-onSeveral-Issues-Concerning-the-Application-of-the-Law-in-Handling-Criminal-Cases-of.html?Article $I D=2780419 \&$ Type= Channel\&ID=9950\&RuleUsed=PageArticle (last visited on Oct. 22, 2012). The 'Opinions' mainly cover the following issues: procedure-related provisions, qualitative issues, conviction and sentencing standards, and method of accumulating illegal incomes, sales volume or business turnover.

45 SPC, Opinions on Several Issues Concerning Fully Leveraging Intellectual Property Trial Functions to Promote the Great Development and Great Flowering of Socialist Culture and to Promote Autonomous and Coordinated Economic Development (关于充分发挥知识产权审制职能作用推动社会主义文化大发展大繁荣和促进经济自主协调发展若干问题的意), 3 FAFA 〈法发〉 (2011), available at http://www.chinalawandpractice.com/Article/2986938/Channel/9930/SupremePeoples-Court-Opinions-on-Several-Issues-Concerning-Fully-Leveraging-Intellectual-Property.html (last visited on Oct. 22, 2012). 
by administrative organs. The enforcement of IP laws by judicial branches is similar to that of many other countries. This paper will focus more on the second kind of activities of the administrative organs. 46

\section{A. Enforcements of IP Laws by Administrative Bodies}

\section{The Administrative Bodies for Enforcing IP Laws}

A dual-track protection system is regarded as a key part of enforcing IP laws in China. This means that both judicial and executive bodies independently carry out their protection of IPRs. Every right-holder can resort to judicial protection when s/he believes that her/his IPRs are infringed. Under certain conditions, the right-holders can also seek administrative reliefs from the three specialized IP administrative organizations and the customs and public security bureaus at different levels.

In China, there are three specialized agencies to deal with the issues concerning the enforcement of IP laws.47 They are as follows: (1) IP offices, which deal with the issues of patent law enforcement; (2) bureaus of copyright administration, which ensure copyright law enforcement; and (3) administrative bureaus for industry and commerce, which have been administering or handling trademark law enforcement and anti-unfair competition law enforcement. Additionally, there are eight other non-specialized administrative organs to enforce the IPRs in particular fields. 48

46 As for the general situations regarding initial regular activities of enforcing patent law undertaken by the SIPO, see Total Applications/Grants/In force for Three Kinds of Patents Received from Home and Abroad, Accumulation Statistics Table of Annual Applications for Three Kinds of Patents, and Distribution of Annual Grants of Three Kinds of Patents to Patentees from Home \& Abroad, Apr. 1985 - Dec. 2011, in SIPO, China Intellectual Property Statistical Yearbook 2011 (available only in Chinese) (2011). As for those of enforcing trademark law undertaken by the SAIC, copyright law undertaken by the NCAC and other IP-related laws, see SIPO, China's Intellectual Property Protection in 2010, available at http://english.sipo.gov.cn/laws/whitepapers/201104/t20110429_ 602312.html (last visited on Oct. 21, 2012).

47 For the functions of the three specialized administrations, refer to its official websites, available at SIPO (http://www.sipo.gov.cn/zcfg); General Administration of Press and Publication of P.R.C.(http://www.gapp.gov.cn/ $\mathrm{cms} / \mathrm{cms} /$ website/zhrmghgxwcbzsww/layout2/zsjj2.jsp?channel $I d=384 \& \operatorname{site} I d=21$ ); the SAIC of the P.R.C. (http://www.saic.gov.cn/english/aboutus/Mission/index.html) (all last visited on Oct. 21, 2012).

48 For details on local offices deal with specific issues concerning IPRs, refer to its official websites, available at Ministry of Agriculture (http://www.moa.gov.cn/sjzz/zzj/sjjszzj/jgznzzj/201112/t20111202_2421994.htm); Ministry of Industry and Information Technology (http://www.miit.gov.cn/n11293472/n11459606/n11459642/11459720.html); General Administration of Quality Supervision, Inspection and Quarantine (http://zfdcs.aqsiq.gov.cn/sjjs/ 200610/t20061030_20956.htm); Ministry of Culture (http://www.ccnt.gov.cn/xxfbnew2011/jgsz/zyzz/ 201111/t20111121_136705.html; MPS (http://www.mps.gov.cn/n16/n80227/index.html); Ministry of Science and Technology (http://www.most.gov.cn) (all last visited on Oct. 21, 2012). Furthermore, there are two other important central organs which do not have the same position as those of ministries and operate local offices to deal with IPR issues: The State Forestry Administration (http://www.forestry.gov.cn/portal/main/s/20/content-69.html); General Administration of Customs (http://www.customs.gov.cn/) (all last visited on Oct. 21, 2012), and their local offices. 
Although each of these administrative organs has its own duties on the enforcement of IP laws, the IPR infringements often involve more than one ministry or commission. It is thus necessary for those organizations to cooperate to enforce IP laws efficiently. In order to rectify serious violations of IP laws the bureaus and administrative organs of culture have to consult with each other for many times. As another example, to create a favorable environment for protecting IPRs during the 2008 Beijing Olympic Games and the 2010 Shanghai Expo, the SPC, the SPP and ten ministries organized a State Working Group of IPR Protection under the leadership of the former Vice Premier $\mathrm{Wu} \mathrm{Yi}{ }^{49}$ to uniformly lead and coordinate national IPR protection. 50

Local governments may also establish IPR executive organs or institutions at local levels. Specialized agencies may also be founded to promote the IP law enforcement in each field. For instance, in August 2004, seven departments collaborated to jointly promulgate a paper entitled "Opinions on Establishing Comprehensive Law Enforcement Authorities of Culture Market in the Comprehensive Pilot Regions of the Cultural System Reform." Since then, $83 \%$ city governments of prefecture-level and $72 \%$ governments of the cities have established such agencies. 51

Furthermore, within particular periods, in order to bar IPR infringement effectively in particular circumstances, special coordination mechanisms for the IPR protection may be established. In early 2008, e.g., the MPS formed a coordination mechanism in the IPR protection with the SAIC, the GAC, and the NCAC; in June 2008, the MPS and the SIPO jointly issued "Circular on the Establishment of Inter-Agency Coordination Mechanism in IPR Protection," which formally shaped the mechanism coordinating the two agencies and offered strong systematic safeguard for tightening the IPR protection.52 Another example at the national level is the National Anti-Piracy and Pornography Office established at the end of August 1989. At local levels, various enforcement authorities have been established according to special demands, such as the Shanghai Cultural Inspection Office, which was founded in December 1999. In addition, the SIPO and other IPR administrations hold the National IPR Enforcement

49 National Intellectual Property Strategy Office ("NIPSO"), The Status of China's Intellectual Property Protection 2004 (June 4, 2010) (2004 年中国知识产权保护状况) (available only in Chinese), available at http://www.nipso.cn/ onews.asp?id=9477 (last visited on Oct. 21, 2012).

50 Yixuan Zhang \& Yong Wang, China Protecting IP Strongly, Both Judicial Protection and Executive Protection Adopted, People's Daily (OverSEAS), May 9, 2007.

51 Fumei Ai, 83\% of Prefecture Level Cities Governments or Area Administrative Offices Have Established Comprehensive Law Enforcement Authorities of Culture Market (July 6, 2011) (全国已有 83\%的地市组建了 文化市场综合执法机构) (available only in Chinese), available at http://news.xinhuanet.com/society/2011-07/06/c_ 13969309.htm (last visited on Oct. 21, 2012).

52 NIPSO, The Status of China's Intellectual Property Protection in 2008, available at http://www.nipso.cn/ onews.asp?id=9600 (last visited on Oct. 21, 2012). 
Assistance Roundtable and encourage individuals and entities to establish particular organizations to enhance IPR enforcement. 53

\section{The Activities of Enforcing IP Laws through Relief Measures Granted by Administrative Bodies}

In the enforcement of general relief measures and special campaigns to protect IPRs, the parties concerned may be more complicated, because the process involves not only right holders and IP administrations, but also the third parties. The administrative organs mainly deal with granting rights, administrative affairs or disputes concerning these rights. On most of these occasions, the disputes concerning IPR infringement are submitted to the courts or arbitrators for adjudication. However, there is a special administrative system of remedies for IPR holders to obtain relief from the IPR infringers. For example, it is clearly provided in Patent Law that:

[i]f a dispute arises as a result of exploitation of a patent without patentee's permission ... the patentee or interested party may take legal action before a court, or request the administration department for patent-related work to handle the dispute; if, when handling the dispute, the said department founds the infringement, it may order the infringer to cease the infringement immediately; ... if the infringer neither takes legal action within the time limit nor ceases the infringement, the said department may file an application with the people's court for compulsory enforcement; the department shall, upon request of the parties, carry out mediation concerning the amount of compensation for the patent right infringement...54

There are two other provisions 55 concerning protection of a patentee's rights through administrative penalty and sanction. It can be inferred from these provisions that the related administrative department has powers to settle the disputes of patent infringement and make the determinations on them. There are similar provisions in Trademark Law,56 Copyright Law,57 Anti-Unfair Competition Law, 58 Regulations on the Protection of New Varieties Plants, 59 Regulations for the Protection of Layout-design of Integrated Circuits, 60 and Regulation for Computer

See China's Intellectual Property Protection in 2011 (二○一一年中国知识产权保护状况) (available only in Chinese), available at http://www.nipso.cn/二。一一年中国知识产权保护状况.pdf (last visited on Oct. 21, 2012).

54 Patent Law art. 60 (2008).

55 Id. arts. 63-64.

56 Trademark Law arts. 53-55.

57 Copyright Law art. 47.

58 Anti-Unfair Competition Law arts. 21 \& 25 (1993).

59 Regulations on the Protection of New Varieties Plants arts. 39-41 (1997).

60 Regulations for the Protection of Layout-design of Integrated Circuits arts. 31-33 (2001). 
Software Protection 61 and other related laws and regulations. All of these provisions compose a fairly systematic institution of administrative protection of IPRs.

Every year, IPR administrations file a number of cases concerning disputes on IPR infringement. In most cases, they make determinations to order infringers to provide remedies to right-holders; the relevant trend in recent years is projected in the Tables below.

Table III-1: Cases Concerning the IP Disputes62

\begin{tabular}{|c|c|c|c|c|}
\hline & $\begin{array}{l}\text { Patent dispute } \\
\text { concerning } \\
\text { infringement }\end{array}$ & $\begin{array}{l}\text { Other patent } \\
\text { disputes }\end{array}$ & $\begin{array}{l}\text { Related to } \\
\text { counterfeiting } \\
\text { patents }\end{array}$ & $\begin{array}{l}\text { Related to passing } \\
\text { off of patents }\end{array}$ \\
\hline 2008 & 1092 & 34 & 59 & 601 \\
\hline 2009 & 937 & 26 & 30 & 548 \\
\hline 2010 & 1095 & 18 & 728 & - \\
\hline
\end{tabular}

Table III-2: Law Enforcement Actions63

\begin{tabular}{|c|c|c|c|l|c|}
\hline & $\begin{array}{l}\text { Person } \\
\text { dispatched }\end{array}$ & $\begin{array}{l}\text { Business } \\
\text { premises } \\
\text { inspected }\end{array}$ & $\begin{array}{l}\text { Goods } \\
\text { checked }\end{array}$ & $\begin{array}{l}\text { Trans- } \\
\text { department } \\
\text { joint } \\
\text { enforcement }\end{array}$ & $\begin{array}{l}\text { Cross-region } \\
\text { enforcement } \\
\text { actions }\end{array}$ \\
\hline 2008 & 17056 & 7671 & 2110822 & 327 & 262 \\
\hline 2009 & 13240 & 6013 & 1322521 & 533 & 204 \\
\hline 2010 & 20646 & 10642 & 2134668 & 545 & 972 \\
\hline 2011 & 175432 & 12346 & 2507859 & 623 & 875 \\
\hline
\end{tabular}

61 Regulation for Computer Software Protection art. 24 (2001).

62 In 2011, nationwide IP offices settled 3017 patent disputes, increased by $65.5 \%$ compared with the number of 2010 , which are not categorized in China's Intellectual Property Protection in 2011.

63 The data are cited from the white papers as follows: The Status of China's Intellectual Property Protection in 2008 2010, available at 2008 (http://www.nipso.cn/onews.asp?id=9600); 2009 (http://www.nipso.cn/onews.asp?id=9599); 2010(http://www.nipso.cn/onews.asp?id=11395) (all last visited on Oct. 2, 2012). The data for 2011 is from China's Intellectual Property Protection in 2011, available at http://www.nipso.cn/UploadFiles/ 二。一一年中国知识产权保护状况.pdf (last visited on Oct. 21, 2012). 
Table III-3: Administrative Enforcement of Trademarks64

\begin{tabular}{|c|c|c|c|c|}
\hline & $\mathbf{2 0 0 8}$ & $\mathbf{2 0 0 9}$ & $\mathbf{2 0 1 0}$ & $\mathbf{2 0 1 1}$ \\
\hline Trademark violations & 56634 & 51044 & 56034 & 79021 \\
\hline $\begin{array}{l}\text { General violations of } \\
\text { trademark rights }\end{array}$ & 9589 & 7448 & 7486 & 10185 \\
\hline $\begin{array}{l}\text { Trademark } \\
\text { infringement and } \\
\text { counterfeiting }\end{array}$ & 47045 & 43596 & 48548 & 68836 \\
\hline $\begin{array}{l}\text { Infringment of a } \\
\text { foreign trademark }\end{array}$ & 10965 & 10461 & 11524 & 17022 \\
\hline Illegal trademark labels removed & 19630000 & 13534000 & 12752200 & 11802249 \\
\hline Cases handed over & 137 & 92 & 175 & 412 \\
\hline Suspects handed over & 145 & 109 & 163 & 415 \\
\hline
\end{tabular}

Table III-4: General Enforcement in the Cultural Market65

\begin{tabular}{|l|c|c|c|}
\hline & $\mathbf{2 0 0 9}$ & $\mathbf{2 0 1 0}$ & $\mathbf{2 0 1 1}$ \\
\hline Officials dispatched & 8419363 & 8145206 & 12251000 \\
\hline Ordered to rectify & 297360 & 131681 & 208000 \\
\hline Received Reports & 62805 & 47816 & 48500 \\
\hline Initiated Investigation & 75857 & 60132 & 63700 \\
\hline Case transferred & 3692 & 2184 & 3504 \\
\hline Finished cases & 65049 & 51248 & 57000 \\
\hline Warnings & 179923 & 120984 & 102000 \\
\hline Fines & 182570000 & 148770000 & 191000000 \\
\hline Confiscations & 2317623 & 1860000 & 4109000 \\
\hline Shut-downs & 37731 & 12378 & 17500 \\
\hline Withdrawals & 632 & 426 & 376 \\
\hline Seized illegal goods & 52382645 & 28100000 & - \\
\hline
\end{tabular}


The facts projected in the Tables depicted that the administrative organs invest much time, money and energy to protect the IPR holders' interests and make significant contributions to improve the enforcement of the IP laws in this way.

\section{Activities of Administrative Organs and Special Protection of IPRs}

In addition to the daily activities of enforcing IP laws, the IPR administrations often wage special nation-wide enforcement campaigns aggressively; initiate assistance to the IPR enforcement; intensify processing of patent disputes; and crack down on the cases of faking patent identity and pseudo-patented products, counterfeiting trademarks and copyright piracy. However, these special campaigns focus on striking at the infringements of copyrights and trademarks.

Before the IPR administrations initiate special campaigns, they make guidelines or similar documents for the protection of IPRs in advance. In February 2008, the SIPO issued the "Circular on the Launch of Thunderstorm and Skynet IP Enforcement Campaigns," demanding the local administrative authorities for patent affairs wage both campaigns for a year. The former aims to combat IPR violations, while the latter tries to address frauds relating to patent. In 2009, the SIPO issued the "Circular on the Arrangement of Recent Enforcement Activities among the IP Offices across the Nation, the Action Plan of 'Thunderstorm' and 'Skynet' Special IPR Enforcement Campaigns in 2009." 66 In 2010, the SIPO issued the "Arrangement of Enforcement Activities among IP Administrations across the Nation in 2010," the "Circular on Printing and Distributing Action Plan for Special Campaign by IP Administrations 2010," the "Circular on Further Paying Close Attention to the Implementation of Task Assignments in Special Campaign," and the "Circular on Strengthening Service for Settlement of Reporting and Complaints by IPR Assistance Centers." 67

SIPO, The Circular on the Arrangement of Recent Enforcement Activities among IP Offices across the Nation, the Action Plan of 'Thunderstorm' and 'Skynet' Special IPR Enforcement Campaigns in 2009 (关于印发《2009年度"雷雨"、 "天网" 知识产权执法专项行动方案》的通知) (available only in Chinese), available at http://portal.soopat.com/ Law/Content/223c935d-d81f-4475-966a-b45a58715602 (last visited on Oct. 21, 2012).

67 SIPO, The Arrangement of Enforcement Activities among IP Administrations across the Nation in 2010," (《关于印发2010年知识产权局系统执法工作安排的通知》, 国知发管字〔2010〕 24号) (available only in Chinese), available at http://www.sipo.gov.cn/wqyz/zcwj/201005/t20100521_519283.html (last visited on Oct. 24, 2012); The Circular on Printing and Distributing Action Plan for Special Campaign by IP Administrations (《关于印发<知识产权局系统执法 专项行动方案〉的通知》国知发管字 (2010〕 34号), (available only in Chinese), available at http://www.sipo.gov.cn/ztzl/ zxhd/ipimplement/ggtz/201011/t20101110_546647.html (last visited on Oct. 24, 2012); The Circular on Further Paying Close Attention to the Implementation of Task Assignments in Special Campaigns (《关于进一步抓紧贯彻落实 专项行动工作部署的通知》, 国知发管字[2010]144号) (available only in Chinese), available at http://china.findlaw.cn/ fagui/xz/08/230703.html (last visited on Oct. 24, 2012); and the Circular on Strengthening Service for Settlement of Reporting and Complaints by IPR Assistance Centers (《关于加强知识产权维援助中心举报投诉维权服务工作的 通知》) (available only in Chinese), available at http://www.sipo.gov.cn/ztzl/zxhd/ipimplement/ggtz/ 
In the field of copyright, in 2009, the NCAC together with the National Anti-Piracy and Pornography Office, the Ministry of Culture ("MOC"), and the Ministry of Education promulgated the "Circular on Strengthening the Copyright Protection Work in Libraries" 68 to improve the copyright administration and protection in libraries. Besides the NCAC, other ministries issued legal documents for launching special campaigns to enforce copyright law. In 2009 and 2010, e.g., the MOC successively issued the "Circular of Carrying out Rectification Actions towards the Culture Market," the "Circular of Organizing Special Rectification Actions towards the Culture Market During the New Year 2010," the "Circular of Rectifying Online Music Market Order and Illegal Activities of Online Music Websites," the "Circular of Concentrated Rectification of Illegal Online Music Websites," and the "Circular of Inspecting and Handling Illegal Animation and Cartoon Products." 69 The purpose of issuing these documents was to make executive bodies carry out a unified deployment of the enforcement work and promote the implementation of various important enforcement activities.

\section{B. General Survey of Regular Enforcements of IP Laws by Judicial Organs}

The daily activities in enforcing IP laws of judicial organs focus on trying civil, criminal and administrative cases involving the infringement of IPRs.70 The People's Courts in China have exerted their efforts to continue to protect IPRs and achieved greatly in the trying of the IPR cases. The overall tendency is that judicial organs issue sanctions against the IPR infringement more severely and definitely. Interests of right holders and the public have been effectively upheld for the past 30 years. The following Tables show data regarding the trials of various courts and the prosecutor's organ from 2008 to 2011.

201011/t20101110_546650.html (last visited on Oct. 24, 2012).

68

SIPO, Circular on Strengthening the Copyright Protection Work in Libraries (关于加强图书馆著作权保护工作的通知) (available only in Chinese), available at http://www.gapp.gov.cn/cms/cms/website/zhrmghgxwcbzsww/layout3/ xxml3.jsp?channel $I d=1385 \&$ site $I d=21 \&$ info $I d=668041$ (last visited on Oct. 22, 2012).

69 Ministry of Culture of the People's Republic of China ("MCPRC"), Normative Documents (政策法项) (available only in Chinese), available at http://59.252.212.6/?classInfoId=21 (last visited on Oct. 22, 2012).

70 By the end of 2011, there are about 119 basic-level people's courts. See SPC, The Circular On Promulgating the Criteria for the Basic-level Courts to Try the First Instance Civil Cases on Intellectual Property Disputes, SPC (2010); SPC, Intellectual Property Protection by Chinese Courts in 2011, available at http://www.dffy.com/sifashijian/ziliao/ 201204/28379_2.html (last visited on Oct. 21, 2012). About 350 intermediate people's courts have jurisdiction over first instance IPR dispute cases, yet there are only $82,45,46 \& 43$ intermediate courts respectively having jurisdictions over dispute cases on patent, new varieties plants, layout-design of integrated circuits and well-known trademark, which need more technological and special knowledge. For more details, see Supreme People's Court of People's Republic of China (available only in Chinese), available at http://www.court.gov.cn (last visited on Oct. 21, 2012). 
Table III-5: Trial of IPR Civil Cases71

\begin{tabular}{|c|c|l|l|l|l|l|c|}
\hline $\mathbf{2}$ & IPR Cases & $\begin{array}{l}\text { Civil } \\
\text { cases }\end{array}$ & $\begin{array}{l}\text { Patent } \\
\text { cases }\end{array}$ & $\begin{array}{l}\text { Trademark } \\
\text { cases }\end{array}$ & $\begin{array}{l}\text { Copyright } \\
\text { cases }\end{array}$ & $\begin{array}{l}\text { Technology } \\
\text { contracts } \\
\text { cases }\end{array}$ & $\begin{array}{l}\text { Other } \\
\text { types of } \\
\text { IPR cases }\end{array}$ \\
\hline $\mathbf{2} 24.52 \% 72)$ & 23518 & $\begin{array}{c}4074 \\
(0.82 \%)\end{array}$ & $\begin{array}{c}6233 \\
(61.69 \%)\end{array}$ & $\begin{array}{c}10951 \\
(50.78 \%)\end{array}$ & 623 & 1340 \\
\hline $\mathbf{2 0 0 9}$ & $\begin{array}{c}30626 \\
(25.49 \%)\end{array}$ & 30509 & $\begin{array}{c}4422 \\
(8.54 \%)\end{array}$ & $\begin{array}{c}6906 \\
(10.80 \%)\end{array}$ & $\begin{array}{c}15302 \\
(39.73 \%)\end{array}$ & 747 & 1967 \\
\hline $\mathbf{2 0 1 0}$ & $\begin{array}{c}42931 \\
(40.18 \%)\end{array}$ & 41718 & $\begin{array}{c}5785 \\
(30.82 \%)\end{array}$ & $\begin{array}{c}8460 \\
(22.50 \%)\end{array}$ & $\begin{array}{c}24719 \\
(61.54 \%)\end{array}$ & $\begin{array}{c}24719 \\
(61.54 \%)\end{array}$ & 1966 \\
\hline $\mathbf{2 0 1 1}$ & $\begin{array}{c}59882 \\
(39.48 \%)\end{array}$ & 58201 & $\begin{array}{c}7819 \\
(35.16 \%)\end{array}$ & $\begin{array}{c}12991 \\
(53.56 \%)\end{array}$ & $\begin{array}{c}35185 \\
(42.34 \%)\end{array}$ & 557 & 2193 \\
\hline
\end{tabular}

Table III-6: Trial of IPR Criminal Cases73

\begin{tabular}{|c|c|c|c|}
\hline & Criminal cases & Suspects sentenced & Suspects found guilty \\
\hline $\mathbf{2 0 0 8}$ & 326 & 5388 & 5386 \\
\hline $\mathbf{2 0 0 9}$ & 3660 & 5836 & 5832 \\
\hline $\mathbf{2 0 1 0}$ & 3942 & 6001 & 6000 \\
\hline $\mathbf{2 0 1 1}$ & 5504 & 7950 & 7892 \\
\hline
\end{tabular}

Table III-7: Trial of Administrative Cases74

\begin{tabular}{|c|c|c|c|c|c|c|}
\hline & $\begin{array}{l}\text { Administra } \\
\text { tive cases }\end{array}$ & $\begin{array}{l}\text { Administra } \\
\text { tive cases } \\
\text { resolved }\end{array}$ & $\begin{array}{l}\text { Patent } \\
\text { cases }\end{array}$ & $\begin{array}{l}\text { Trademark } \\
\text { cases }\end{array}$ & $\begin{array}{l}\text { Copyright } \\
\text { cases }\end{array}$ & $\begin{array}{l}\text { Other } \\
\text { types of } \\
\text { cases }\end{array}$ \\
\hline $\mathbf{2 0 0 8}$ & 1074 & 1032 & 578 & 484 & 7 & 5 \\
\hline $\mathbf{2 0 0 9}$ & 2072 & 1971 & 688 & 1376 & 4 & 4 \\
\hline $\mathbf{2 0 1 0}$ & 2590 & 2391 & 551 & 2026 & 2 & 11 \\
\hline $\mathbf{2 0 1 1}$ & 2433 & 2470 & - & - & - & - \\
\hline
\end{tabular}

71 Supra note 63.

72 In this table, the percentages indicate the annual growth rates of the numbers of cases compared to the previous year, e.g., the number of cases in 2008 as compared to the number of cases in 2007.

73 Supra note 63.

74 Id. 
Table III-8: Activities of the Prosecutor's Organ75

\begin{tabular}{|l|c|c|c|c|c|c|c|}
\hline & $\begin{array}{l}\text { Arrest } \\
\text { approval } \\
\text { applications } \\
\text { accepted }\end{array}$ & $\begin{array}{l}\text { Suspects } \\
\text { involved }\end{array}$ & $\begin{array}{l}\text { Approved } \\
\text { arrests of } \\
\text { suspects }\end{array}$ & $\begin{array}{l}\text { Approved } \\
\text { arrest cases }\end{array}$ & $\begin{array}{l}\text { Prosecution } \\
\text { applications } \\
\text { accepted }\end{array}$ & $\begin{array}{l}\text { Suspects } \\
\text { involved }\end{array}$ & $\begin{array}{l}\text { Suspects } \\
\text { prosecuted }\end{array}$ \\
\hline $\mathbf{2 0 0 8}$ & 1407 & 2565 & 2107 & 1210 & 1770 & 3482 & 2697 \\
\hline $\mathbf{2 0 0 9}$ & 1492 & 2667 & 2119 & 1256 & 1931 & 3518 & 2695 \\
\hline $\mathbf{2 0 1 0}$ & 1887 & 3368 & 2613 & 1556 & 2207 & 4122 & 3066 \\
\hline $\mathbf{2 0 1 1}$ & 4370 & 7806 & 5952 & 3532 & 5690 & 11147 & 6870 \\
\hline
\end{tabular}

\section{The Chinese Government's Initiative to Enforce the IPRs and the TRIPs Agreement: An Analysis}

As shown above, it is obvious that the Chinese government has established a comprehensive IP legal system to comply with the provisions of major international IP treaties including the TRIPs Agreement.76 China's determination to deter crime and infringement of IPR is steadfast; it has adopted or founded more measures and bodies than any other countries to enhance IPRs and is making relevant laws, some of which are not even the obligations of the WTO members. For instance, the TRIPs Agreement only provides that any person who commits "willful trademark counterfeiting or copyright piracy on a commercial scale will be accused of criminal liabilities." 77 In China, however, the Criminal Law and the Patent Law provide that a person who counterfeits the patent of another person shall bear not only civil and administrative liabilities, but also criminal liabilities.78 If convicted, the defendant shall be sentenced to a fixed-term imprisonment of not more than three years or criminal detention, and may be concurrently or independently sentenced to a fine. ${ }^{79}$ According to these provisions, every year, patent administrations transfer several cases to the public security bureau to

75 Id.

76 The United States also acknowledges that the Chinese IPR legislation is in compliance with the TRIPs and mainly disputes the thresholds for the imposition of criminal penalties and the adequacy of the various monetary penalties imposed by the Chinese authorities. See Council for Trade-Related Aspects of Intellectual Property Rights, Report to the General Council by the Chair: Transitional Review Under Section 18 of the Protocol on the Accession of the People's Republic of China, IP/C/39, Nov. 2005, at 55-59.

77 TRIPs Agreement art. 61.

78 Patent Law art. 63 (2008).

79 Criminal Law art. 216 (2011). 
investigate and proceed with criminal procedures. The Chinese government has fully recognized that protecting IPRs would encourage innovation.

The IPRs are basically private rights, typically protected as civil or commercial interests through civil procedure or arbitration. Right-holders themselves would have the primary obligation to enforce their claimed rights and take necessary legal actions. 80 In this regard, the TRIPs Agreement provides that:

Members shall ensure that certain enforcement procedures are available under their law so as to permit effective action against any act of IPR infringement, especially civil judicial procedures concerning IPR available to right holders covered by it,, 81 they are not bound to make additional judicial mechanisms available for IPR enforcement in addition to those of their other laws. 82

Obviously, the members are obliged to ensure that enforcement procedures available rather than to provide relief measures for right holders directly. If members have made enforcement procedures, they have fulfilled their obligations. In the U.S., patent protection is provided for in the Constitution and generally patent disputes are settled by the federal courts according to 28 U.S.C., "Judiciary and Judicial Procedure." 83 The Bonito Boats v. Thunder Craft Boats case held that: "States may not offer patent-like protection to intellectual creations which would otherwise remain unprotected as a matter of federal law." 84 According to the manual of patent examining procedure, patents are enforced by bringing a civil law suit and lawsuits for patent infringement may only be brought to a Federal Court. 85 Thus, the right-holders can only protect their patent rights by civil procedures before the federal courts.

In any case, the "principle of autonomy" is the ground for private business and "no trial without complaint" is the fundamental principle for the court to file the cases. There are few occasions for a country to sign international treaties or agreements on the enforcement of civil laws; it is the private sectors' own duties to conduct or act according to the laws at their will. As far as the enforcement of IP laws is concerned, developed countries adopt different attitudes. They would demand developing

\footnotetext{
80 European Commission Directorate General for Trade, Strategy for the Enforcement of Intellectual Property Rights in Third Countries 3 \& 12, available at http://trade.ec.europa.eu/doclib/docs/2010/december/tradoc_147070.pdf llast visited on Oct. 21, 2012).

81 TRIPS Agreement arts $41, \uparrow 1 \& 42$.

82 Id. art. $41,95$.

8328 U.S.C. $§ 1331$. It provides that the district courts shall have original jurisdiction of all civil actions arising under the Constitution, laws, or treaties of the United States.

84 Bonito Boats v. Thunder Craft Boats, Inc., 489 U.S. 141, 156 (1989), available at http://supreme.justia.com/cases/ federal/us/489/141/case.html (last visited on Oct. 21, 2012).

85 United States Patent and Trademark Office ( “USPTO”), Manual of Patent Examining Procedure (8th ed. 2010).
} 
countries enforce IP laws by way of governmental measures forcing private sectors to observe them.

In developed countries, right holders of private properties have to protect their rights mainly by civil procedures. Nonetheless, their governments and enterprises often criticize the governments of developing countries for not enforcing IPRs effectively and press the latter to adopt administrative measures. According to international trade practices, if a right holder launches a lawsuit in a host country which has no judicial procedure to protect IPRs, or its judicial branches are not willing to protect IPRs, then the host government shall assume international obligations. ${ }^{86}$ In spite of the internationally recognized judicial procedures for protecting IPRs, developed countries often impose pressures on the Chinese government in various ways to demand administrative protections of IPRs. For the dual-track approach, most enterprises from developed countries are not actually willing to follow civil procedures first; 87 they tend to make use of administrative measures to protect their private rights. In this case, developing countries are forced to spend enormous public resources from their taxpayers just to protect the private rights of a small group of people. 88 As mentioned above, the Chinese government has spent tremendous time and resources on special campaigns to fight IPR infringement. All public servants and officials participating in the activities are paid from the government treasury which is established through amounts paid by the Chinese people as tax. A similar system does not exist and is not likely to be seen in the U.S., Japan or European countries; those countries do not protect private interests of small groups of people by sacrificing the interests of the majority of their people without permission from their respective legislative branches.

In April 2007, the United States launched a complaint 89 alleging that China did not

86 For details, see Ligang Zou, On the Principle of Exhaustion of Local Remedies in International Law, 5 JouRNAL OF LAW (法学研究). (1994); and Jianqiu Huang \& Bing Feng, The Principle of Exhaustion of Local Remedies and the Disputes Settlement under the Framework of GATT/WTO, 6 LAW REv. (法学评论). (2005).

87 There are many examples, and here we may just mentioned the cases concerning trademarks. For the details, see Trademark Bureau of the State Administration for Industry and Commerce, Ten Typical Cases of Protecting Registered Trademarks of Foreign Enterprises by the Administrations for Industry and Commerce All Over China 2009, 5 China Trademark (中国商柿) (2010); Ten Typical Cases of Protecting Registered Trademarks of Foreign Enterprises by the Administrations for Industry and Commerce All Over China 2006, 9 BiweEkLY OF ADMIN. FOR INDUSTRY \& COM. (2007).

88 In China, the administrative organs have duties to deal with the disputes on IPR infringement. For details, see Jianzhi Deng, Administrative Protection for Intellectual Property Rights in China under the Framework of WTO, INTELL. PROP. PRESS 200-236 (2009). To some degree, the administrative approach may not be appropriate for IPRs are private ones. If their holders' rights are infringed, they shall sue the infringers for reliefs and shall not utilize the public powers or organs to protect their rights which are financially supported or funded by taxes. In other word, we shall not use the taxpayers' money to protect a small number of individual's private rights.

89 See China-Measures Affecting the Protection and Enforcement of Intellectual Property Rights, Panel Report WT/DS362 (Jan. 30, 2008), available at http://www.ifta-online.org/sites/default/files/58.pdf (last visited on Sept. 15, 
perform its obligations under the TRIPs Agreement in the following four aspects: (1) the lack of criminal procedures and penalties for commercial scale counterfeiting and piracy; (2) the requirement that infringing goods generally be released into the channels of commerce; (3) Clause 4.1 of China's Copyright Law which made it impossible for certain rights holders to enforce their copyrights or related rights; and (4) certain cases of willful copyright piracy on a commercial scale was not subject to criminal procedures and penalties. On January 26, 2009, the panel report was circulated; the third allegation and part of the second allegation were supported, while the others were denied. 90 The main reason for China to lose part of the case was attributed to different understandings of both Clause 4.1 and related stipulations in the Regulations on Customs Protection of Intellectual Property Rights and the interpretation of the related provisions in the TRIPs Agreement and the Berne Convention. This shows that, even before 2007, most of the legislation on enforcing IPRs in China were consistent with the TRIPs Agreement. Before the end of March 2010, China revised its Copyright Law 91 and Regulations on Customs Protection of Intellectual Property Rights. ${ }^{92}$ Therefore, there are no or few gaps in enforcing IP laws between what China has done and what the TRIPs Agreement is asking. 93 The key problem, however, is how to realize the stipulations, some of which are out of the government's control.

\section{What Makes Enforcing IP Laws Difficult in China?}

Today, the Chinese government is doing its best controlling IPR infringement. However, it still finds difficulty to fully implement enforcement in the real market. For instance, piracy of copyright is still seen; in field of trademarks, counterfeiting the registered trademark of another or passing off a fake as genuine has been pervasive

2012).

90 Supra note 22 (WT/DS362/R).

91 In 2010, Clause 4.1 of Copyright Law (2001) was abrogated and the maintained part of Article 4 was revised slightly. See Copyright Law (2010) art. 4 .

92 The following sentence was added to Clause 27.3 of the revised Regulations on Customs Protection of Intellectual Property Rights: "With regard to counterfeit trademark goods, the simple removal of the trademark unlawfully affixed shall not be sufficient, other than in exceptional cases, to permit release of the goods into the channels of commerce."

93 Some foreign scholars express the similar opinion. For example, K. Athanaakou holds that it is difficult to clarify what the minimum enforcement standard of the TRIPs actually is, while Chinese IPR provisions may constitute sufficient minimum standards under the TRIPS, despite claims that Chinese IPR could be more effective, thus better or best, if some changes were made. See K. Athanaakou, China IPR Enforcement: Hard as Steel or Soft as Tofu? Bring the Question to the WTO under TRIPs, 39 GEO. J. INT'L L. 237-240 (2007). 
across some regions. The government of China holds that potential deficiencies in full compliance of the TRIPs in its territory are due to lack of public awareness regarding IPR, lack or inadequate training of the judges or other IPR administrators, and the overall need of the Chinese economy to adapt to the new global market requirements. 94 Under these backgrounds, the following are the more detailed reasons why enforcing IP law is difficult in China.

First, the IP laws of China were enacted not because of China's endogenous economic and social demands, but because of certain international or foreign influences from the beginning. 95 Many terms or articles were directly transplanted from the IP laws of foreign countries or international treaties which might not be in line with Chinese conditions. In fact, the level of the legislation cannot exceed the level of a nation's socio-economic development, education, and awareness of laws. Some negative impacts were produced by foreign factors which indirectly blocked China's comprehensive attempts to enforce IP laws.

Currently, the Chinese government has been trying to improve the situation by creating social awareness towards the significance of the IPRs in private sectors and the harmful effects of the IPR infringement. Nonetheless, IP laws have not yet been fully complied with by enterprises, individuals and other organizations mainly because most IPR infringers are self-employed households or individual business, or small enterprises, such as those in the form of workshops. These businesses run very flexibly and thus evade investigation and prosecution easily. When the enforcement bodies come to investigate, e.g., they can easily close their factories and then re-open facilities once the authorities leave. This is usually known as a "hide-and-seek" game or "fighting as a guerrilla" by the enforcement bodies. 96 On some occasions, the infringers take advantage of the public's indifference to IPR protection to agitate or stir up some of the public to attack or revile against the law-executors, which forms great barriers to the execution of IP law and provides chances for the infringers to escape punishment or sanctions.

Second, local protectionism forms heavy impediments to the enforcement of IP laws. About 10 years ago, it was pointed out that, when a local government forms and implements economic policy, it would actively protect or maintain illegal benefits for 
local regions in order to maximize local benefits. 97 In our opinion, the statement is exaggerated, considering that not all local governments adopted local protectionism policies. However, local protection had been very serious before 2003. Even since then, the central government and local governments have fought over local protectionism. Nonetheless, local protection still exists, which is a big barrier to implementation of IP laws.

The typical forms of local protectionism include the following: discrimination between local and non-local enterprises; protection umbrellas for illegal activities such as manufacturing and selling counterfeit or pirated products, polluting the environment; setting up obstacles to prevent the products or services from other parts of the country from entering the local market; intervening in the activities of enforcement by the courts, the prosecutors' office or other enforcement bodies. 98 For instance, when it is required to cooperate with the governments of other regions in which the rightholders live, the officials of the region do not cooperate and may fail to provide any help, or simply not consider the issues seriously. They would sometimes connive to commit the IPR infringement. In the past, even some local governments, under a pretext of "knowing nothing about the truth," encouraged IPR infringement by improper actions or policies such as providing support to enterprises which might make contributions to the development of local economy while the "achievements" may be attributed partly to the IPR infringement. ${ }^{99}$ In some places, the local governments establish certain areas with special protection; no enforcement authorities are allowed to enter into and inspect the enterprises in these areas without the approval of the local governments. Even in other regions, in order to maintain rapid growth of the GDP and stable taxes, the local governments impose pressures on the local courts or prosecutors to protect local enterprises when they deal with the IPRs dispute cases between local and foreign enterprises, 100 or between local enterprises and universities/research institutions.

A recent case is the dispute between an enterprise located in a province in Southwest

97 D. Chow, Organized crime, local protectionism, and the trade in counterfeit goods in China, 14 CHINA ECON. REV. 473-484 (2003).

98 Jun-qi Liu, Analysis on Local Protectionism in Market Economy, 12 Productrvity ReSEARCh (2010); Yingfeng Li, Viewing on the Harms Caused by Local Protectionism in Aspect of the Continuous Fight against Counterfeit and Shoddy Products but not Preventing Completely, 1 China BRAND AND ANTI-CounTERfeiting (2012); baidu.com, Local Protectionism (地方保护主义), available at http://baike.baidu.com/view/876.htm (last visited on Oct. 21, 2012); G. Feder, Enforcement of Intellectual Property Rights in China: You Can Lead a Horse to Water, but You Can't Make It, 37 VA. J. INT'L L. 223 (1996).

99 Supra note 96.

100 Xiaoyu Yang, On Counterfeit and Shoddy Products and Local Protectionism, 7 ChINA QUALITY Supervision (2006). See also Yanqin Shen, On the Harms to Judicial Equity Caused by, 4 J. Changsha U. (2008). 
China and the patent holders concerning heat transmission from Tsinghua University. The former exploited the patents without any authority of the latter. The latter launched a suit against the former to protect the legal rights and claimed damages caused by the former's infringement. Under the influence of local protectionism, however the local courts (including the first-instance court and the appellate court) made judgments adverse to the plaintiff. Then, the plaintiff appealed the judgment to the Supreme Court of the People's Republic of China which finally made a judgment in support of the plaintiff. ${ }^{101}$ If local protectionism cannot be contained effectively, 102 it will continue to constitute a certain 'umbrella' to protect IPR infringers and make it more difficult to enforce IP laws.

Third, the severity or intensification of punishment or sanctions against the IPR infringement is not enough to frighten existing or potential infringers into cessation of their violations of IP laws. Inadequate punishment for counterfeiting and plagiarism is one of the imperfections of China's IP laws.103 In the current IP laws, compensatory liabilities, not punitive damages liabilities, are the remedies for right-holders; this may not deter present and potential infringers. Article 65 of the Patent Law provides that:

The amount of compensation for patent right infringement shall be determined according to the patentee's actual losses caused by the infringement; if it is hard to determine the actual losses, the amount of compensation may be determined according to the benefits acquired by the infringer through the infringement ... the amount of compensation shall include the reasonable expenses paid by the patentee for putting an end to the infringement; if the losses of the patentee, benefits of the infringer, or royalties of the patent are all hard to determine, the people's court may ... determine the amount of compensation within the range from 10,000 yuan to $1,000,000$ yuan. 104

The calculation method of compensation is too rigid and the ceiling amount of compensation when it is difficult to determine the actual loss is too small. In order to effectively deter patent infringement, the method and the ceiling amount should be more flexible and much higher.

101 During the period of the judgment complained to the Supreme Court, the officials of the local department of intellectual property rights visited the rightholders of the patents to beg for leniency for the defendant. See Jinna, Wu, A Famous University (Tsinghua)'s Road to Protect Its Rights with a Loss: Trial of Intellectual Property Meeting Local Protectionism (知识产权官司遭遇 “地方保护主义”一所名牌高校的“赔本” 维权路), DAILY OF SCI. \& TECH., Mar. 9, 2012.

102 In the latest years, China has gained great achievements in the field of beating local protectionism. See Li Ma, Zhang Wei'an: Carry Protection for Intellectual Property through to the End, 11 Faren MaGazine (2008). However, it is not easy to eradicate it in a short time, and there is still a long way for China to go in this field.

103 Supra note 95, at 141.

104 Patent Law art. 65 (2008). 
As for criminal liabilities for IPR infringement, the maximum statutory penalty is seven years of fixed-term imprisonment with a fine. 105 Regarding copyright infringement, the Criminal Law provides that:

Whoever, for the purpose of reaping profits, has committed one of 4 acts of copyright infringement listed in the law and gains a fairly large amount of illicit income, or when there are other serious circumstances, is to be sentenced to not more than three years of fixed-term imprisonment, criminal detention, and may in addition or exclusively be sentenced to a fine; when the amount of the illicit income is huge or when there are other particularly serious circumstances, he is to be sentenced to not less than three years and not more than seven years of fixed-term imprisonment and a fine. 106

Such a light criminal punishment cannot be a strong deterrent to the crime of copyright infringement. Generally, if an infringer suffers a loss of his/her whole family's fortune or a loss of personal freedom because of her/his infringement of IPRs, s/he or other potential violator may learn from this experience and may stop committing any IPR infringement. 107

Fourth, the unfair price of genuine IPR products is an indirect reason for IPR infringement. Infringement of IPRs often attracts the public interest, because pirated works or products, made without paying license royalties, always are much cheaper than the legal copies. In developing countries, because people do not have enough income to accommodate a genuine copy, the enticement to purchase cheaper copies or products will exist all the time. The average price of some IP-related products, such as Microsoft Windows in developing countries is at least $20-30 \%$ higher than that of the same products sold in developed countries.108 A most efficient way to reduce the IPR

105 The conclusion is drawn on the basis of the provisions from Articles 213-219 of Criminal Law (2011), which respectively provide the criminal liabilities of trademark infringement, patent infringement, copyright infringement and trade secret infringement.

106 Criminal Law art. 217 (2011).

107 The United States is one of the countries which adopts the most severe punishment for IP infringement at present time, and it provides some experiences to other countries in aspect of enforcing IPRs. See Hu-Zhao Ma \& Hui Ma, International Experiences of Intellectual Property Law Enforcement in Foreign Trade and Implications for China, 25 INT'L ECON. \& TRADE RES. (2009).

108 For instance, in 1990s, the price of the Microsoft Windows 98 in the Unites States was about USD 89, less than daily wage of an ordinary worker; while the price of the same software sold in China was about JPY 1980 Yuan (nearly USD 240 at that time), which was worth of about two or three monthly salaries of an ordinary worker in China. See Jingkang Ma, Copyright, Microsoft, Software in China, ComPUter World, Nov. 1, 1999). Qiangdong Liu believes that it is not because Chinese people like to use pirated software, but because the software of Microsoft is sold at a much higher price, which is 2-5 times of that in foreign countries. See Qiangdong Liu, It Is Not that Chinese People Like to Use Pirated Software, But that the Software of Microsoft Is Sold Much More Expensively 
infringement in developing countries is thus to balance the prices in a fair way.

Fifth, legal culture should be considered when enforcement of laws is discussed. The traditional legal culture of China does not fully respect positive laws. For a long time in the history of China, people's consciousness of laws was very dim and the positive functions of law were neglected or even denied. 109 Even today, many people still have faint legal awareness, especially in the aspect of the awareness of protecting IPRs. 110 These unfavorable conditions for enforcing IP laws cannot be solved within a short time. Thus, a very important step is to improve people's consciousness of obeying laws. 111

In addition, Chinese IP laws were originally drafted and revised by the so-called power elites in China including scholars, experts or technocrats at different times without full discussion and soliciting public ideas. Most people may not realize the importance of IP because they would not recognize these laws themselves. This may prevent the Chinese government from effectively enforcing IP laws.

\section{Conclusion: Ways Out}

Intellectual property is basically a 'Western' concept in a modern sense.112 Today, however, it is applied in an 'Asian context.' 113 Adopting the Western models of IP law, China is seeking compliance with the major international IP conventions, all of which

in China (Apr. 19，2011) (刘强东:不是中国人喜欢盗版而是微软卖太贵) (available only in Chinese), available at http://tech.sina.com.cn/i/2011-04-19/14435423890.shtml (last visited on Oct. 22, 2012).

109 For details, see Ming Yang, Analysis of the Current Situation of Chinese Public's Legal Knowledge, 44 J. PekING U. 2007; Liu Jiazeng, Zhang Guixiang \& Ye Guan, Brief Discussion on the Cultivation of Legal Awareness for the NonLaw Professional University Students, 6 China Construction Edu. (2008); Qiming Jiang, Analysis of the Fundamental Contradictions of the Changing Legal Consciousness in the Transitional Period in China, 5 J. YUNNAN Admin. Inst. (2011).

110 For details, see Qingjie Sun \& Guobin Chu, Analysis of the Current Situation of the Public's Awareness of Intellectual Properties in China and the Countermeasures, 9 J. SuzHou U. (2011); Hongjun Chen, Awareness of Intellectual Properties and China's Traditional Culture, 23 DATA of Culture and Educ. (2007); and Hua Liu \& Ying Zhou, Survey of Chinese Public's IP Protection Awareness and Some Recommendations, 10 ChINA Soft ScI. (2006).

111 See Yang, supra note 109; Liu \& Zhou, supra note 110.

112 Actually, in ancient China, they did not develop the modern concept of intellectual property, which has been universally accepted by majority of Chinese scholars. Today, in China, it is often defined as "any creative work or invention or marks containing commercial factors or any other intellectual achievement, such as knowhow, considered to be the property of its creator or producer, which shall mainly include copyright, patent, trademark and so." See HANDONG WU, Intellectual Property LaW 5, 30 (3rd ed. 2009); and Chuntian Liu, Intellectual Property LaW 3 (3rd ed. 2007).

113 W. Alford, To Steal a Book is an Elegant OfFEnse 7 (1995). 
are basically derived from the European and American experiences.114 This genesis is a main obstacle to the enforcement of IP laws. Nonetheless, the Chinese have paid much attention to protecting the IPRs under the actual Chinese situations. In most countries, administrative organs mainly focus on granting exclusive rights, managing IPR issues, resolving disputes regarding ownership of IPRs, and sanctioning lawbreakers. In addition to these roles, the Chinese executive sectors sometimes deal with issues of infringement of the IP (including settlement of the disputes on compensation), which in other countries are settled by judicial sectors. This has been regarded as a "Chinese characteristic of the IPR protection" system by foreign joint ventures.115

As mentioned in this paper (Part II), China's legislation of IPRs has been heavily influenced by international organizations or foreign countries. However, statutes are significant only when they are enforced effectively.116 Enforcement is different from legislation; external environments or pressures may weaken enforcement. ${ }^{117}$ Enforcement of IP laws depends on many factors such as people's awareness of protecting IPRs, economic and social development level and other conditions. It depends not only on the governments, but also on the cooperation and active actions of individuals and enterprises. 118

In order to eliminate the difficulties of enforcing IP laws in China, the most important thing is that people's awareness of protecting IPRs by abiding by laws should be improved in the whole society. More people should recognize that infringement of the IPRs is a violation of law and a serious crime. When a critical case is at issue, the

114 Ren We, Beverage 'Vitasoy' and its Trademark Registration, 4 China Patents \& TRADEMARKS, $42-44$ (1986).

115 Jianzhi Deng, Study on the Development Trend of the Unique IPR Administrative Protection System in China, 6 China Soft Science 2008. See also Lin Dai, On Administrative Protection for Intellectual Property and Establishment of Administration Organs in China, 6 J. YunNAN U. L. EdITION (2010).

116 Naigen Zhang, Intellectual Property Law Enforcement in China: Trade Issues, Policies and Practices, 8 FordHAM INTELL. PRop. Media \& ENT. L. J., 65 (1997).

117 The agreements under the WTO can only impose direct impacts on its members' domestic legislation, and may produce indirect impacts on enforcement through legislation to remove the provisions related to enforcement which are not in compliance with the WTO rules. This is the main reason why the US, Japan, the EU and several other countries concluded the ACTA outside of the WTO framework. The negotiating countries of the ACTA believe that under the TRIPs Agreement to enhance IPR enforcement.

118 One scholar suggests that there are three alternatives that may help to solve China's problem of enforcing IP laws: The first requires that China curtail the corruption in its government, or work to make enforcement of intellectual property rights a responsibility of the central government; the second requires that an economic incentive be created, by China or by the international community, to make the counterfeiting industry in China less profitable or unprofitable as compared to the manufacture and production of non-counterfeit goods; and the third requires that the WTO and the international community punish China and make China accountable for its failure to improve enforcement mechanisms within its borders. See P. Rezler, Breaking through the Great Wall: Problems of Enforcement of Intellectual Property Rights in China, 14 TouRo InT'L L. REv. 258-259 (2010). In our opinion, these solutions, especially the second one, seem reasonable, but are impracticable; they may not fully understand China's situations or international law regarding liabilities. 
media should disclose the information to let more people know it.

To encourage universal recognition of the IP laws in China, the following ways are recommended: First, higher education institutions should list the IPR law courses as compulsory ones in the curriculum for the college students. In addition, legal training centers shall also be established to promote awareness of protection of IPRs. Then, the IPR enforcement system should be reorganized because there are too many bodies enforcing IPR, which may create conflicts among them. In addition, their duties are not clear, which creates very common mutual shuffles which may harm enforcement of IP laws. In order to avoid these negative effects, the government's organs should be downsized according to the principles of simplified administration, unified action and higher efficiency. Furthermore, co-operation among different governmental departments regarding IPR enforcement should be strengthened. It is urgent to centralize the power for IPR enforcement by unifying or merging the current executive bodies to a smaller number with certain focuses on different aspects of IPR enforcement.

Second, China should punish those who violate IP laws more severely, possibly even including life imprisonment or the death penalty. Severe punishment makes infringers afraid of violating the laws again and simultaneously produces dreadful awe to potential infringers, with the function of "beating the dog before the lion" (to warn the many by punishing a few). In our opinion, some counterfeit products are much more dangerous, especially those concerning the public health (such as counterfeit medicines), so it may be reasonable to set the death penalty as the maximum punishment for the criminals who manufacture or distribute these products under particular situations. 119 We do not believe that this would violate the UN principle of fundamental human rights.

Third, it is to find a way to crack down on local protectionism. This is a very complicated question in the field of enforcing not only IP laws, but also other laws. From a perspective of IP law enforcement, the ideal way may be to establish a unified nationwide IPR court system, which should not be affected by the local governments when IPR cases are tried.

Finally, if the gap in technological development levels among the countries were rather small and if the price of IPR products were not too expensive in developing countries (unreasonable compared with the average income of their nationals), it would be much easier to enforce IP laws. In order to implement IP laws effectively, China should improve its technology level and encourage enterprises to innovate by themselves in two ways: (1) developing and introducing their own advanced

119 In China, the death penalty includes two kinds: immediate execution and death sentence with two-year reprieve. On most occasions, the criminals sentenced to the latter will not be executed. See Criminal Law art. 48 (2011). 
technologies; and (2) completely depending only on themselves to produce original innovation. Obviously, the former is preferred for the enterprises. If developed countries perform their obligations to transfer their technologies under reasonable conditions, an obligation to which they have committed themselves in international IPrelated treaties, the Chinese enterprises will save much time and cost in research and development. Later, they may also increase their innovation capacities and further be able to provide IP-related products with reasonable prices. If so, it will indirectly help to enforce IP laws to a certain degree. This is probably the most effective way to solve the problems of enforcing IPRs in China. 
